\title{
Patala-Nammal Composite Total Petroleum System, Kohat-Potwar Geologic Province, Pakistan
}

\author{
By C.J. Wandrey, B.E. Law, ${ }^{2}$ and Haider Ali Shah ${ }^{3}$ \\ ${ }^{1}$ U.S. Geological Survey, Denver, Colorado. \\ ${ }^{2}$ Consultant, Lakewood, Colorado. \\ ${ }^{3}$ Oil and Gas Development Corporation, Ltd., Islamabad, Pakistan.
}

\section{Foreword}

\section{ByThomas S. Ahlbrandt}

This report describing the petroleum resources within a total petroleum system in Pakistan was prepared as part of the World Energy Assessment Project of the U.S. Geological Survey. For this project, the world was divided into 8 regions and 937 geologic provinces, which were then ranked according to the discovered oil and gas volumes within each (Klett and others, 1997). Of these, 76 "priority" provinces (exclusive of the United States and chosen for their high ranking) and 26 "boutique" provinces (exclusive of the United States and chosen for their anticipated petroleum richness or special regional economic importance) were selected for appraisal of oil and gas resources. The petroleum geology of these priority and boutique provinces is described in this series of reports.

The purpose of the World Energy Project is to assess the quantities of oil, gas, and natural gas liquids that have the potential to be added to reserves within the next 30 years. These volumes either reside in undiscovered fields whose sizes exceed the stated minimum-field-size cutoff value for the assessment unit (variable, but must be at least 1 million barrels of oil equivalent) or occur as reserve growth of fields already discovered.

The total petroleum system constitutes the basic geologic unit of the oil and gas assessment. The total petroleum system includes all genetically related petroleum that occurs in shows and accumulations (discovered and undiscovered) and that (1) has been generated by a pod or by closely related pods of mature source rock, and (2) exists within a limited, mappable geologic space, along with the other essential, mappable geologic elements (reservoir, seal, and overburden) that control the fundamental processes of generation, expulsion, migration, entrapment, and preservation of petroleum. The minimum petroleum system is that part of a total petroleum system encompassing discovered shows and accumulations along with the geologic space in which the various essential elements have been proved by these discoveries.

An assessment unit is a mappable part of a total petroleum system in which discovered and undiscovered fields constitute a single, relatively homogenous population such that the chosen methodology of resource assessment based on estimation of the number and sizes of undiscovered fields is applicable. A total petroleum system may equate to a single assessment unit, or it may be subdivided into two or more assessment units if each unit is sufficiently homogeneous in terms of geology, exploration considerations, and risk to assess individually.

A graphical depiction of the elements of a total petroleum system is provided in the 
form of an event chart that shows the times of (1) deposition of essential rock units, (2) trap formation, (3) generation, migration, and accumulation of hydrocarbons, and (4) preservation of hydrocarbons.

A numeric code identifies each region, province, total petroleum system, and assessment unit; these codes are uniform throughout the project and will identify the same type of entity in any of the publications. The code is as follows:

Region, single digit

Example

Province, three digits to the right of region code

Total Petroleum System, two digits to the right of province code

Assessment unit, two digits to the right of petroleum system code

The codes for the regions and provinces are listed in Klett and others (1997).

Oil and gas reserves quoted in this report are derived from Petroconsultant's

Petroleum Exploration and Production database (Petroconsultants, 1996) and other area

reports from Petroconsultants, Inc., unless otherwise noted.

Figure(s) in this report that show boundaries of the total petroleum system(s),

assessment units, and pods of active source rocks were compiled using geographic information-

system (GIS) software. Political boundaries and cartographic representations

were taken, with permission, from Environmental Systems Research Institute's ArcWorld

1:3,000,000 digital coverage (1992), have no political significance, and are displayed

for general reference only. Oil and gas field center points, shown on these figures, are

reproduced, with permission, from Petroconsultants (1996).

\section{Contents}

Foreword

Introduction

Acknowledgments

Regional Geologic History

Stratigraphy.

Production History.

Composite Petroleum System

Source Rock.

Maturation

Generation and Migration

Reservoir Rocks

Traps and Seals.

Assessment Unit

Assessment of Undiscovered Oil and Gas.

Summary.

Selected References 


\section{Figures}

1. Map showing location of the Kohat-Potwar geologic province.

2. Generalized geology of the Kohat-Potwar geologic province and surrounding area...

3. Generalized structure of Kohat-Potwar geologic province area

4. Extent of total petroleum systems in the Kohat-Potwar geologic province area.

5. Generalized stratigraphy of the Kohat-Potwar area.

6.-11. Paleogeographic maps of the:

6. Middle Jurassic (approximately $166 \mathrm{Ma}$ ).

7. Early Cretaceous (approximately $130 \mathrm{Ma}$ )

8. Late Cretaceous (approximately $94 \mathrm{Ma}$ )

9. Latest Cretaceous (approximately $69 \mathrm{Ma}$ )

10. Middle Eocene (approximately $50 \mathrm{Ma}$ )

Figures- cont

11. Late Oligocene Epoch (approximately $27 \mathrm{Ma}$ )

12. Generalized cross section showing structure through the Potwar Plateau

13. Generalized oil and (or) gas field and structure map of Kohat-Potwar area

14. Plot showing the cumulative number of new-field wildcat wells versus well-completion year

15. Maturity of exploration indicator plots showing known and grown (expected final size when production is ended) field sizes grouped in thirds by age of discovery and ranked by size...

16. Plots showing cumulative known and grown oil volumes versus the cumulative number of new-field wildcat wells.

17. Plot showing field size versus field-discovery year

18. Plot showing reservoir depth versus oil-field-discovery year

19. Generalized cross section showing structure through the Potwar Plateau.

20. Generalized burial-history plots for the ODGC Dakhni 1 well and the Gulf Oil Fim Kassar well ........

21. Distribution of producing reservoirs by age and number of fields in which they occur

22. Distribution of producing reservoirs by age, lithology, and number of fields reporting production from that age group and lithology type

23. Petroleum system events chart for the Kohat-Potwar geologic province

\section{Tables}

1. Estimates of undiscovered oil and gas for the Patal-Nammal composite total petroleum system, KohatPotwar geologic province (8026), Pakistan

2. Expected size distribution for undiscovered oil fields in the Kohat-Potwar geologic province ........

3. Expected size distribution for undiscovered gas fields in the Kohat-Potwar geologic province...... 


\section{Introduction}

Among the 26 boutique provinces identified for the World Energy Assessment Project was an onshore, oilprone area named the Kohat-Potwar geologic province (fig. 1). The province (part of the upper Indus Basin) is bounded on the north by the Parachinar-Murree fault, on the west by the Kurram fault, on the south by the Surghar and Salt Ranges, and on the east by the Jehlum fault (figs. 2 and 3). The area includes the Potwar and Kohat Plateaus and Bannu Depression. The Kohat-Potwar province consists of a portion of the Indian plate structurally deformed by plate collision and overthrust of the Himalayas on the north and northwest. Important structural features (fig. 3) include a series of faulted and unfaulted anticlines developed on multiple detachment surfaces as deep as Cambrian and thrust faults that trend generally southwest-northeast parallel to the plate-collision boundary.

\section{Acknowledgments}

Most of the data presented in this report was provided by the Oil and Gas Development Corporation (OGDC), Islamabad, Pakistan, and Amoco Production Co., Houston, Texas. We are especially grateful to Mr. Marten James of Amoco for his help in obtaining geologic data from Pakistan.

The authors thank technical reviewers E.A. Johnson and Peter Warwick for their valuable suggestions and insight.

\section{Regional Geologic History}

The total petroleum system (TPS) and assessment unit (AU) discussed herein (fig. 4) acquired their primary structural and stratigraphic features from events associated with plate movements that occurred from latest Paleozoic to the present. From Permian through Middle Jurassic time, the Indian plate was located in the Southern Hemispherebetween the African, Antarctic, and Australian plates-and comprised part of southern Gondwana. The Lower Permian Tobra Formation tillites (fig. 5) in the Kohat-Potwar area and other basal Permian glacial deposits on the Indian plate are indicative of a much cooler paleoclimate (Shah, 1977). The area that is now the Indus Basin, Kohat-Potwar geologic province, and northern India, was a shallow continental shelf on which carbonates, shales, and sandstones were deposited. This carbonate-dominated environment persisted at least intermittently on the western part of the shelf through the Late Jurassic and is represented by the interbedded shales and thick limestones of the Springwar Formation and as much as 1,400 $\mathrm{m}$ of the Middle and Upper Jurassic Sulaiman Limestone Group on western and northern portions of the plate. In the area that is now the Kohat-Potwar geologic province, shelf and shallow-marine stages are preserved in the rocks of the Permian Nilawahan, Permian and Triassic Zaluch, Triassic Musa Khel, and Jurassic and Cretaceous Surghar Groups. During the Late Jurassic, Madagascar, India, Australia, Antarctica, and the Seychelles began to break away from Africa, forming the Somali Rift Basin (figs. 6 and 7). Late Jurassic rifting also initiated separation of Australia and Antarctica from India.

During Early Cretaceous time, the Indian plate drifted northward, entering warmer latitudes. Along the eastern portion of the Indian plate, the Rajmahal Trap volcanics were deposited. On the northwest margin of the plate, marine shales and limestones of the Lower Cretaceous Sembar and Goru Formations were deposited over a regional erosional surface on the Sulaiman Group. In the Kohat Potwar area, this erosional surface is present at the top of the Samana Suk 
Formation and is overlain by sandstones and shales of the Lower Cretaceous Chichali Formation. On the eastern shelf of the Indian plate, the Bolpur and Ghatal Formations were deposited. Whereas carbonates are recognized primarily on the eastern and western shelves today, it is likely that they were deposited over much of the northern shelf as well. This shelf environment persisted through the Late Cretaceous when regressive sandstones such as the Lumshiwal and Pab Formations in the west and Tura Formation in the east were deposited. During the latest Cretaceous, the Indian plate continued to drift northward toward the Eurasian plate and the seafloor of the Bengal Basin began to form and flysch accumulated on all sides of the Indian plate (fig. 8).

Northward plate movement continued during the Late Cretaceous, and a transform fault became active along the Ninety-East Ridge (fig. 9). Rifting between Madagascar and the Seychelles portion of the Indian plate initiated formation of the Mascarene Basin. Extensional faulting occurred as the western part of the Indian plate sheared southward relative to the main plate (Kemal and others, 1992). Counterclockwise rotation of the Indian plate was initiated, and the Seychelles portion of the Indian plate began to break away (Waples and Hegarty, 1999) (fig.9).

Latest Cretaceous was also a time of intense volcanism in western India, with the expulsion of the Deccan Trap basalts and further rifting, which began, and then failed, leaving the Cambay and Kutch grabens floored with the Deccan Trap basalts (Biswas and Deshpande, 1983). The rifting event in the Cambay and Kutch areas might be related to the extensional faulting and shear zone that was developing at the same time in the Indus Basin.

From the Late Cretaceous through middle Paleocene, trap deposits and basal sands continued to accumulate on the western, northern, and eastern shelves of the Indian plate (fig. 10). Oblique convergence of the Indian plate with the microplates constituting the southern edge of the Eurasian plate resulted in wrench faulting and development of regional arches such as the Jacobad and Sargodha highs in the Indus Basin (fig. 2) (Kemal and others, 1992).

The Indian plate continued to move northward at an accelerated rate of $15-20 \mathrm{~cm} / \mathrm{yr}$ (Scotese and others, 1988). When the eastern edge of the plate passed over the Kerguelen hot spot, a chain of islands began to form near long $90^{\circ} \mathrm{E}$. Continued northward movement and counterclockwise rotation of the Indian plate slowly closed the Tethyan Sea along the northern and northwestern plate boundaries. The Sulaiman-Kirthar fold belt (Province 8025, fig. 1) began to develop as a result of this oblique collision and rotation. Regional uplift and the resulting mountain ranges rising on the Eurasian plates to the north and west created a new sediment source, and the prevailing south to north sediment transport direction on the Indian plate was reversed. From Eocene through middle Miocene, a carbonate platform buildup occurred intermittently on the shelves around much of the Indian plate. A trench formed along the subduction zone as the Indian plate began to slip beneath the Eurasian plate (fig. 11). The Eurasian plate shed large volumes of sediments into the trench as subduction continued. This terrestrial sediment influx from the rapidly rising Himalayan, Sulaiman-Kirthar, Sino-Burman, and Indo-Burman Ranges significantly exceeded carbonate buildup rates on late Miocene platforms (Roychoudhury and Deshpande, 1982) and smothered carbonate reef formation along the shelf areas. The former shelf areas along the collision zones were either subducted or became emergent fluvial-deltaic environments. In the Kohat-Potwar geologic province shallow northeast-trending anticlines and overturned folds developed above multiple detachment surfaces (fig. 12). Detachment surfaces as deep as the Eocambrian salts developed as a result of continued plate convergence, and associated crustal shortening of as much as $55 \mathrm{~km}$ occurred (Jaswal and others 1997; Kemal and others, 1992).

The proto-Indus, Narmada, Ganges, Brahmaputra, Megna, Chindwin, and Irrawaddy Rivers developed extensive deltas as the Himalayas and other ranges continued to shed sediments at a high rate. Today, uplift of the 
Himalayas and subduction of the Indian plate continues, and the growth rate of the Indus, Ganges-Brahmaputra (Megna), and Irrawaddy deltas remains high. In the Kohat-Potwar area, crustal shortening also continues.

\section{Stratigraphy}

The Kohat-Potwar geologic province depositional record is relatively complete from Late Proterozoic to Holocene (fig. 5). Late Proterozoic metamorphic basement rocks are overlain by oil-impregnated shales, sandstones, and interbedded carbonates and evaporates of the Late Proterozoic and Lower Cambrian Salt Range Formation. The upper part of the Salt Range consists of thick carbonates overlain by evaporites marking the top of the formation. Potential source beds and oil shows have been identified within the evaporite sections (Shah, 1977; Iqbal and Shah, 1980). The thickness of the Salt Range Formation varies from 50 to more than $1,000 \mathrm{~m}$, due partly to dissolution of these evaporates. Above the Salt Range, evaporites are as much as $150 \mathrm{~m}$ of marine shales and massive sandstones representing braided-stream deposits of the Lower Cambrian Jhelum Group, Khewra Formation, which has produced oil at the Adhi, Chak Naurang, and Rajian fields (Khan and others, 1986; Petroconsultants, 1996) (fig. 13). As much as 180 $\mathrm{m}$ of the Kussak Formation glauconitic shoreface sandstones and siltstones overlie the Khewra. The Kussak has produced oil at the Missa Keswal field (Petroconsultants, 1996). The overlying Jutana Formation consists primarily of sandy carbonates and nearshore sandstones. The Upper Cambrian Baghanwala Formation shales and interbedded sandstones in the Potwar Plateau and Salt Range area, and contemporaneous Khisor Formation salts in the Kohat area, mark the top of the Cambrian stratigraphic sequence. The top of this sequence also marks the beginning of a hiatus that lasted until the Permian.

The Permian Nilawahan Group consists of the Tobra Formation glacial tillites, siltstones, and shales; the Dandot Formation alluvial or glacial coarse-grained sandstones and shales; the Warchha Formation coarse-grained argillaceous sandstones, and occasional shales; and the Sardhai Formation, which is similar to the Warchha except for a greater number of fine-grained-sandstone intervals (Shah, 1977; Iqbal and Shah, 1980; Kemal, 1992). Three fields in the southeast portion of the Potwar Plateau have produced oil or gas from Tobra reservoirs. Overlying the Nilawahan Group is the Zaluch Group consisting of Upper Permian Amb Formation shelf carbonates, Wargal Formation shelf-carbonate sequences, and the Chhidru Formation marls and coarsening upward sandstones. The Wargal has produced oil at the Dhurnal field.

Although Mesozoic rocks are generally preserved in the Salt Range and southeast Potwar Basin, part or all of the section is missing from the Kohat Plateau and northwestern Potwar deformed zone (Jaswal and others, 1997). Depositional thinning toward the west combined with erosion accounts for the missing rocks. Deposited on the unconformable Permian strata are continental, coarse- to fine-grained sandstones, shales, and carbonates of the Triassic Musa Kehl Group Mianwali and Tredian Formations. Overlying the Tredian are shelf carbonates of the Triassic Kingriali Formation. The Triassic Formations were formerly referred to collectively as the Wulgai Formation (Shah, 1977). The Jurassic strata include the Shirinab or Datta and Shinawari Formations consisting of nearshore variegated siliciclastics that contain some nonmarine-sandstone intervals (Khan and others, 1986). The Datta has produced oil and gas from three fields, including Dhulian, in the northwest Potwar Plateau area. Overlying these nearshore formations are as much as $900 \mathrm{~m}$ of Samana Suk Formation platform carbonates. The Lower Cretaceous section consists of Chichali Formation basinal shales, Sembar and Lower Goru Formations coarsening-upward shoreline packages (late highstand), and Lumshiwal Formation sandstones (maximum basin flooding surface). The Upper Goru, Kawagarh, or upper 
Moghul Kot siliciclastics representing Late Cretaceous lowstand events are present southeast of the Salt Range and on the Kohat Plateau but are not reported within the Potwar Basin.

Cenozoic deposition began with the Paleocene-Eocene Makarwal Group. Hangu Formation siliciclastics were deposited first on an erosional surface marking the top of the Cretaceous Lumshiwal Formation. There is a transitional contact between the Hangu and Pab and the overlying Lockhart Formation carbonate-shelf system. The contact between the Lockhart and the shallow-marine shales and subordinate carbonates of the Patala Formation is also transitional (Shah, 1977; Iqbal and Shah, 1980; Kemal, 1992). Oil production has been attributed to the Lockhart and Patala. The overlying Eocene Nammal and Panoba Formations are shallow-marine to lagoonal shales and interbedded limestones with a transitional contact between the Patala and the Nammal. Overlying the Nammal and Panoba are the lower Eocene Sakesar or Margala Hill Formation marine limestones and shales. Oil or gas production from eight fields spanning the Potwar Plateau are attributed to the Margala Hill. Even though Iqbal and Shah (1980) indicated that the probably contemporaneous lower Eocene Bahadur Khel Salt is present only in the Kohat Plateau area (fig. 5), oil or gas production at three fields on the Potwar Plateau has been attributed (Petroconsultants, 1996) to the Bahadur Khel Salt Formation (Shah, 1977; Petroconsultants, 1996). The Chharat Group includes marine shales and interbedded limestones of the lower Eocene Chorgali Formation, the shales of the upper Eocene Kohat Formation, and the highstand shales and ramp carbonates of the Oligocene Kirthar Formation that were deposited at least in the Kohat and northern Potwar area. Oligocene rocks are missing from most of the basin. An erosional surface marks a change to alluvial environments represented by the Miocene to Pliocene Murree Formation fluvial sandstones and siltstones and the Kamlial Formation fluvial sandstones and clays of the Rawalpindi Group. The Murree Formation contains the youngest reported oilproducing reservoirs in the Kohat-Potwar geologic province. Pliocene and Pleistocene Siwalik Group fluvial sandstones and conglomerates mark the top of the stratigraphic column in the area.

\section{Production History}

In 1866, the first oil well on the western Indian subcontinent was drilled at Kundal (fig. 13). The first commercial oil discovery occurred in 1914 when the Attock Oil Company completed a 214-ft well on a thrust-faulted anticline near the town of Khaur (Khan and others, 1986) (fig. 13). Since the discovery, there have been more than 340 wells drilled in the field. Production at Khaur is from Sakesar and Murree Formation reservoirs. Drilling from 1920 to 1935 resulted in success at Dhulian, a structural dome $17 \mathrm{~km}$ southeast of Khaur. Other discoveries followed with Joya Mair in 1944, Balkassar in 1946, Karsal in 1956, and Tut in 1967 (fig. 13). The first commercial gas field—Adhi-was found in 1979. The Adhi gas field produced from rocks ranging in age from Cambrian to Eocene (Petroconsultants, 1996). Eighteen oil and three gas fields were discovered in the Kohat-Potwar geologic province between 1915 and 1996, and several prospects that were unsuccessfully tested in the 1950s and 1960s are now being reexamined with good results (Quadri and Quadri, 1998). Production in the Kohat-Potwar geologic province comes primarily from faulted anticlinal traps in rocks ranging in age from Cambrian to Miocene, and at depths of less than $20 \mathrm{~m}$ to greater than $1,030 \mathrm{~m}$. The largest oil and gas field found to date is the Dhurnal field with areal closure of $13.5 \mathrm{~km}^{2}$ and vertical closure of $500 \mathrm{~m}$. The initial in-place oil estimate for Dhurnal was $102 \mathrm{MMBO}$ (million barrels of oil) (Jaswal and others, 1997)

The plot of cumulative new-field wildcat wells versus completion year for the Kohat-Potwar geologic province (fig. 14) shows that the rate of field discovery through time has increased. The known oil fields ranked by size and 
grouped in discovery thirds does not show a significant decrease in field size in progressive thirds (fig. 15). The small decrease in field size through time indicates that the province is still not mature in terms of exploration. A mature province would show a larger decrease in field sizes between the first and third thirds. The small range of field sizes shown in figure 15 may also be the result of relatively consistent thrust mechanisms creating many anticlinal traps of similar volume and orientation. The size of oil fields discovered during the second and third of the exploration history further indicates that, even though the prospective area is small and appears well explored, potential remains for the discovery of additional medium and small fields. The plot showing cumulative oil volumes found versus the cumulative number of new-field wildcats (fig. 16) shows a consistent level of effort required to find similar volumes of oil. In a more mature area, the number of wildcat wells required to find the same volume of oil would be expected to increase and the curves on the plots to flatten. The number of gas-field discoveries was insufficient to create a meaningful plot. The size of the largest oil fields discovered through time has remained consistent (fig. 17), but there has been a significant increase in the discovery rate for smaller fields. Exploration for deeper targets has increased, but shallow fields are still being found (fig. 18). The largest field may have already been found, but potential for additional oil and gas discoveries in complex structural traps remains good.

\section{Composite Petroleum System}

\section{Source Rock}

The U.S. Geological Survey (USGS) recognizes that there are several individual total petroleum systems in this area. For assessment purposes, however, they were combined into a single composite Eocambrian-Miocene TPS (the Patala-Nammal TPS, 802601) because few correlations of source to reservoir hydrocarbons were available at the time of the assessment. In addition, multiple stacked sources and reservoirs-and extensive fault systems-allow the mixing of hydrocarbons from multiple sources making further subdivision more difficult. The Paleocene Patala Formation appears to be the primary source of hydrocarbons, but other potential source rocks may be contributing in different parts of the basin.

There are several potential source rocks in the Kohat-Potwar geologic province. These include the Late Proterozoic-Lower Cambrian Salt Range; Permian Wargal, Sardhai, and Chhidru; Paleocene Lockhart; and Eocene Patala Formations (OGDC, 1996; Quadri and Quadri, 1996). Most of the available information and analyses available was derived from samples collected on the Potwar Plateau and easternmost Kohat Plateau. The remainder of the Kohat Plateau source-rock potential is not as well known. Correlated columnar sections (Shah, 1977) show a generalized thinning of the Paleocene-Eocene stratigraphic sequences toward the southwest part of the Kohat Plateau. Lower Cretaceous Sembar and Lower Goru temporal equivalents—-the Chichali and Lumshiwal Formations—may be the youngest mature rocks with source potential throughout most of the Kohat Plateau.

The oldest potential source rocks are in the Salt Range Formation, which consists of a clastic-dominated lower section, carbonate-dominated middle section, and an evaporite-dominated upper section. Potential source-rock intervals are found primarily in the upper evaporite sequence. The Permian Sardhai and Chhidru, although sandy, have sufficiently high total organic carbon (TOC) values to have source-rock potential (Quadri and Quadri, 1997). The shallow-marine shales of the Eocene Patala Formation, ranging in thickness from 20 to $180 \mathrm{~m}$, are the probable 
predominant oil source in the Potwar Basin (OGDC, 1996, oral commun.). Patala TOC ranges from 0.5 percent to more than 3.5 percent, with an average of 1.4 percent, and are type-II and -III kerogens. The exception to this may be the Dhurnal field (fig. 14), where Patala samples have low TOC values, whereas TOC values in the Permian Wargal are 1.0 percent and in the Lockhart they are 1.4 percent (Jaswal and others, 1997). Oil samples from Dhurnal field also do not match those known to be sourced by the Patala. Sulfur content of the oils is less than 0.65 percent, except at Joyamair where sulfur content is greater than 2 percent (Khan and others, 1986).

\section{Maturation}

Thermal maturities for Kohat-Potwar rocks range, from $\mathrm{R}_{\mathrm{o}} 0.3$ to more than 1.6 percent. A basin profile (OGDC, 1996) indicates vitrinite reflectance equivalent maturities of 0.62 to 1.0 percent for Tertiary rocks in the productive part of the Potwar Basin (fig. 19). Fluid-inclusion data, with vitrinite-reflectance data used for calibration, shows calculated and measured $\mathrm{R}_{\mathrm{o}}$ samples between 0.6 and 1.1 percent for Cretaceous, 0.5 to 0.9 percent for Jurassic, and 0.65 to 0.95 percent for Permian rocks (Tobin and Claxton, 2000). North of the main boundary thrust fault, maturities are higher. In the northern and probably central basin, Cretaceous rocks are in the 1.0 to 1.6 percent $R_{o}$ range. Dry gas generation begins near 1.3 percent $\mathrm{R}_{0}$.

\section{Generation and Migration}

Generation of hydrocarbons most likely began in Late Cretaceous time for Cambrian through Lower Cretaceous source rocks and again from Pliocene time to the present for younger source rocks (OGDC, 1996). Burialhistory plots by Law and others (1998) (fig. 20) start at about $30 \mathrm{Ma}$ and therefore show only a late or second period of generation beginning 20 to $15 \mathrm{Ma}$ and continuing to the present. Two distinct over pressuring regimes were reported by Law and others (1998). A Neogene over pressuring regime was attributed to tectonic compression and under compaction, and a pre-Neogene over pressuring regime is attributed to combined hydrocarbon generation and tectonic compression The burial-history plots of Law and others (1998) also indicate that maximum burial was reached approximately 2 million years ago. Even though there were probably two distinct periods of generation from two different groups of source rocks, sufficient source-to-reservoir correlation data were not available to clearly define separate petroleum systems. In many oil and gas fields, there are stacked source and reservoir rocks possibly resulting in mixing of oils. Migration is primarily over short distances updip and vertically into adjacent reservoirs and through faults and fractures associated with plate collision and thrusting.

\section{Reservoir Rocks}

Reservoir rocks include Miocene alluvial sandstones, Paleogene shelf carbonates, Jurassic and Permian continental sandstones, and Cambrian alluvial and shoreface sandstones (Shah, 1977; Iqbal and Shah, 1980). On the Potwar Plateau, oil or gas has been produced from the following formations: Cambrian Kherwa, Kussak, and Jutana; Permian Tobra, Amb, and Wargal; Jurassic Datta; Cretaceous Lumshiwal; Paleocene Khairabad, Lockhart, Patala, and Nammal; Eocene Bhadrar, Chorgali, and Margala Hill Limestone; and Miocene Murree (Khan and others, 1986; Petroconsultants, 1996) (fig. 5). Production from more than one of these reservoirs (in one case five reservoirs) was 
reported at 12 of the 22 fields in the database (Petroconsultants, 1996). More than 60 percent of the producing reservoirs (by field) are of Cenozoic age (fig. 21), with the majority of those being Eocene carbonates.

Sandstone porosities range from less than 5 percent to 30 percent and average 12 percent to 16 percent. Permeability ranges from less than 1 millidarcy $(\mathrm{mD})$ to greater than $300 \mathrm{mD}$, with the average ranging from 4 to 17 $\mathrm{mD}$ (Khan and others, 1986). At the Dhurnal field and probably elsewhere in the basin, hydrocarbons in the carbonate reservoirs are primarily from tectonically induced fracture porosity on strike with structural trends (Jaswal and others, 1997). Approximately 60 percent of the identified producing reservoirs are carbonates (fig. 22).

Because oil and gas production volumes are reported by field rather than reservoir in the database used (Petroconsultants, 1996) and 12 of 21 fields reported production from more than one reservoir, no attempt was made to assign volumes of oil and gas to reservoirs, ages, or lithologies.

\section{Traps and Seals}

Most of the fields discovered in the Kohat-Potwar geologic province to date are either overturned faulted anticlines, popup structures, or fault-block traps. In this area, anticlinal features strike generally east-northeast to westsouthwest and are approximately parallel to the plate-collision zone. Many of these folded structures are amplified, or they are only present above a detachment zone in Eocambrian salts. The latest trap-forming thrust events began at approximately 5 and $2 \mathrm{Ma}$ (Jaswal and others, 1997). Seals include fault truncations and interbedded shales and the thick shales and clays of the Miocene and Pliocene Siwalik Group .

\section{Assessment Unit}

The Kohat-Potwar Intrathrust assessment unit (AU) (80260101), is also a composite. The rocks of this AU include sandstones, shales, and coals of deltaic to fluvial facies and carbonates and shales of shelf environments and range in age from Eocambrian to Miocene.

\section{Assessment of Undiscovered Oil and Gas}

Based on data current to 1996 provided by Petroconsultants International Data Corporation, the Kohat-Potwar geologic province was ranked 174th in cumulative production and reserves of oil and gas worldwide (Klett and others, 1997). The Kohat-Potwar geologic province (8026) did not meet the minimum cumulative production cutoff to be included in the assessment as a priority province, but due to its long history of oil production, remaining potential, and geologic and geographic relationship with the rest of the Greater Indus Basin, it was categorized as a boutique province for the USGS World Petroleum Assessment 2000 (U.S. Geological Survey World Energy Assessment Team, 2000). Known petroleum volumes are 0.3 billion barrels of oil (BBO) and 1.9 trillion cubic feet of gas (TCFG) for a total of 0.7 billion barrels of oil equivalent (BBOE) including natural gas liquids (Petroconsultants, 1996); this volume is less than 0.1 percent of world volume (excluding the United States). In the Kohat-Potwar geologic province 18 oil and 3 gas fields had been discovered by 1996 (Petroconsultants, 1996).

Previous estimates of undiscovered oil and gas in this region include those by Kingston (1986) and Masters and others (1998). Kingston (1986) estimated the mode of undiscovered oil in the Kohat-Potwar province at 0.1 BBO 
and gas at $0.1 \mathrm{TCF}$. Masters and others (1998) estimated the mean for undiscovered oil in this province as $0.12 \mathrm{BBO}$ and the mean for undiscovered gas as 3.0 TCF. The methodology utilized in those assessments employed analogs from well-known productive regions of the world and also relied heavily on volumetric considerations.

The 2000 assessment incorporates the petroleum system concept as defined by Magoon and Dow (1994). The TPS used as the geologic basis of the 2000 assessment in the Kohat-Potwar geologic province is the Patala-Nammal TPS (802601). Tables 1, 2, and 3 show the estimated ranges of assessed undiscovered oil and gas volumes allocated by assessment unit and the totals for the composite Patala-Nammal TPS.

\section{Summary}

Source-rock quality in the Kohat-Potwar geologic province is fair to good in numerous stratigraphic intervals (fig. 23). Burial depths were in the past, and are today, great enough for continued generation from many of these source intervals. The Paleocene and Eocene source intervals have been in the oil and gas generation window in parts of the Kohat-Potwar geologic province for as long as 15 m.y., and, in places, generation continues today. Reservoirs are of fair to very good quality and exist in close proximity to source rocks. The presence of stacked reservoirs greatly improves opportunities for discoveries. Trap development, although widespread, was relatively late but coincided with maximum burial and probably maximum hydrocarbon generation. Continued crustal shortening and uplift in some cases enhanced trap quality and in others diminished or destroyed it. Complex structures and over pressuring, although creating exploration and drilling challenges, also offer additional opportunities. Further opportunities also exist in the Kohat Plateau area where few wells have been drilled, but source-rock quality or thickness may be lower. The northern folded zone also has potential, although structural complexity makes exploration difficult.

\section{Selected References}

Ahmad, S., Alam, Z., and Khan, A.R., 1996, Petroleum exploration and production activities in Pakistan: Pakistan Petroleum Information Service, $72 \mathrm{p}$.

Biswas, S.K., and Deshpande, S.V., 1983, Geology and hydrocarbon prospects of Kutch, Saurashtra, and Narmada Basins: Petroleum Asia Journal, v. 6, no. 4, p. 111-126.

Drewes, H.,1995, Tectonics of the Potwar Plateau region and the development of syntaxes, Punjab, Pakistan: U.S. Geological Survey Bulletin 2126, $25 \mathrm{p}$.

Environmental Systems Research Institute Inc., 1992, ArcWorld 1:3M digital database: Environmental Systems Research Institute, Inc. [ESRI], scale: 1:3,000,000, [available from ESRI, Redlands, Calif.].

Government of Pakistan, 2001, Privatisation Commission Finance Division: Government of Pakistan Web page, [URL <www.gopsale.com/index.htm?press_release.htm\&2>].

Iqbal, M.W.A., and Shah, S.M.I., 1980, A guide to the stratigraphy of Pakistan: Quetta, Geological Survey of Pakistan Records, v. 53, p. 34.

IHS Energy Group [formerly Petroconsultants], 2001, Probe 4.0 petroleum exploration and production database:Englewood, Colo., IHS Energy Group [database available from IHS Energy Group, 15 Inverness Way East, D205, Englewood, C0 80112, U.S.A.includes data current as of September 2001].

Jaswal, T.M., Lillie, R.J., and Lawrence, R.D., 1997, Structure and evolution of the northern Potwar deformed zone, Pakistan: American Association of Petroleum Geologists Bulletin, v. 81, no. 2, p. 308-328. 
Johnson, E.A., Warwick, P.D., Roberts, S.B., and Khan, I.H., 1999, Lithofacies, depositional environments, and regional stratigraphy of the lower Eocene Ghazij Formation, Balochistan, Pakistan: U.S. Geological Survey Professional Paper 1599, 76 p.

Kazmi, A.H., and Rana, R.A., 1982, Tectonic map of Pakistan: Geological Survey of Pakistan, scale: 1:2,000,000.

Kemal, A., 1992, Geology and new trends for hydrocarbon exploration in Pakistan, in Ahmed, G., Kemal, A., Zaman, A.S.H., and Humayon, M., eds., New directions and strategies for accelerating petroleum exploration and production in Pakistan: Proceedings, international petroleum seminar, November, 22-24, 1991: Islamabad, Pakistan, Ministry of Petroleum and Natural Resources, p. 16-57.

Kemal, A., Balkwill, H.R., and Stoakes, F.A., 1992, Indus Basin hydrocarbon plays, in Ahmed, G., Kemal, A., Zaman, A.S.H., and Humayon, M., eds., New directions and strategies for accelerating petroleum exploration and production in Pakistan: Proceedings, international petroleum seminar, November, 22-24, 1991: Islamabad, Pakistan, Ministry of Petroleum and Natural Resources, p. 76-105.

Khan, M.A., Ahmed, R., Raza, H.A., and Kemal, A., 1986, Geology of petroleum in Kohat-Potwar Depression, Pakistan: American Association of Petroleum Geologists Bulletin, v. 70, no. 4, p. 396-414.

Kingston, J., 1986, Undiscovered petroleum resources of South Asia: U.S. Geological Survey Open-File Report 86-80, 131 p.

Klett, T.R., Ahlbrandt, T.A., Schmoker, J.W., and Dolton, G.L., 1997, Ranking of the world's oil and gas provinces by known petroleum volumes: U.S. Geological Survey Open-File Report 97-463, one CD-ROM.

Law, B.E., Shah, S.H.A., and Malik, M.A., 1998, Abnormally high formation pressures, Potwar Plateau, Pakistan, in Law, B.E., Ulmishek, G.F., and Slavin, V.I., eds., Abnormal pressures in hydrocarbon environments: American Association of Petroleum Geologists Memoir 70, p. 247-258.

Magoon, L.B., and Dow, W.G., 1994, The TPS—From source to trap: American Association of Petroleum Geologists Memoir 60.

Malik, Z., Kemal, A., Malik, Azam M., and Bodenhausen, J.W.A., 1988, Petroleum potential and prospects in Pakistan, in Raza, H.A. and Sheikh, A.M., eds., Petroleum for the future, Islamabad.

Masters, C.D., Root, D.H., and Turner, R.M., 1998, World conventional crude oil and natural gas identified reserves, undiscovered resources, and futures: U.S. Geological Survey Open-File Report 98-468, 105 p.

Peeock, E.S., Lillie, R.J., Zaman, A.S.H., and Yousaf, M., 1989, Structural interpretation of seismic reflection data from eastern Salt Range and Potwar Plateau, Pakistan: American Association of Petroleum Geologists Bulletin, v. 73, p. 841-857.

Oil and Gas Development Corporation [OGDC], 1995, Pakistan petroleum prospects—An overview: Islamabad, Oil \& Gas Development Corporation, $22 \mathrm{p}$.

Oil and Gas Development Corporation [OGDC], 1996, Pakistan petroleum prospects—An overview: Islamabad, Oil \& Gas Development Corporation, $22 \mathrm{p}$.

Petroconsultants, 1996, Petroleum exploration and production database: Petroconsultants, Inc., [P.0. Box 740619, 6600 Sands Point Drive, Houston TX 77274-0619, U.S.A. or Petroconsultants, Inc., P.0. Box 152, 24 Chemin de la Mairie, 1258 Perly, Geneva.

Powell, C. M.A., 1979, A speculative tectonic history of Pakistan and surroundings; some constraints from the Indian Ocean, in Farah, Abdul, and Dejohn, K.A., eds., Geodynamics of Pakistan: Geological Survey of Pakistan, p. 5-24.

Quadri, Viqar-un-Nisa, and Quadri, S.M.G.J., 1996, Exploration anatomy of success in oil and gas exploration in Pakistan, 1915-94, 0il and Gas Journal, v. 94, i. 20.

Quadri, V.N., and Quadri, S.M.J.G., 1998, Failure-to-success targets may lie in Pakistan basins: Oil and Gas Journal archives, v. 96, i. 1, [accessed 3/2/2000 at URL <http//ogj.pennwellnet.com>].

Quadri, V.N., and Quadri, S.M.J.G., 1998, Pakistan has unventured regions, untested plays: Oil and Gas Journal archives, v. 96, i. 12, [accessed 3/2/2000 at URL <http//ogj.pennwellnet.com>].

Quresihi, M.J., Tariq, M.A., and Abid, 0.Z. [Raza, S.M., Hussain, A., and Khan, S.H., eds.], 1993, Geological map of Pakistan: Geological Survey of Pakistan, scale 1:1,000,000.

Scotese, C.R., Gahagan, L.M., and Larson, R.L., 1988, Plate tectonic reconstructions of the Cretaceous and Cenozoic ocean basins: Tectonophysics, v. 155, p. 27-48.

Scotese, C.R., 1997, PALEOMAP Software, Paleomap project, [available at URL http://scotese.com]. 
Sercombe, W.J., Stratton, M., Albertin, M., Wilson, W.P., Roth, B.L., Van Nieuwenhuise, R., Pivnik, D.A., and Beck, R.A., 1994, Wrench faulting in the northern Pakistan foreland region: The Leading Edge, November 1994, p. 1107-1110.

Sercombe, W.J., Pivnik, D.A., Wilson, W.P., Albertin, M.L., Beck, R.A., and Stratton, M.A., 1998, Wrench faulting in the northern Pakistan foreland: American Association of Petroleum Geologists Bulletin, v. 82, no. 11, p. 2003-2030.

Shah, S.M. Ibrahim, ed. 1977, Stratigraphy of Pakistan: Geological Survey of Pakistan, Memoirs, v. 12, 137 p.

Soulsby, A., and Kemal, A., 1988, A review of exploration activity in Pakistan: Oil and Gas Journal, November 21, 1988, p. 56-59.

Soulsby, A., and Kemal, A., 1988, Source rock maturity key to new plays: Oil and Gas Journal, November 28, 1988, p. 81-83.

Raza, H.A., 1992, Petroleum source rocks in Pakistan, in Gulfaraz, A., Kemal, A., Zaman, A.S.H, and Humayon, M., eds., New directions and strategies for acceleration petroleum exploration in Pakistan: Islamabad, Pakistan, Proceedings of an international petroleum seminar, Ministry of Petroleum \& Natural Resources, Nov. 22-24, 1991, p. 129-136.

Roychoudhury, S.C., and Deshpande, S.V., 1982, Regional distribution of carbonate facies, Bombay offshore region, India: American Association of Petroleum Geologists Bulletin, v. 66, no. 10, p. 1483-1496.

Tobin, R.C., and Claxton, B.L., 2000, Multidisciplinary thermal maturity studies using vitrinite reflectance and fluid inclusion microthermometry; A new calibration of old techniques: American Association of Petroleum Geologists Bulletin, v. 84, no. 10, p. 1647-1665.

Wandrey, C.J., and Law, B.E., 1999, Map showing geology, oil and gas fields, and geologic provinces of South Asia: U.S. Geological Survey Open File Report 97-470C, version 2, one CD-ROM.

Wandrey, C.J., Milici, R.C., and Law, B.E., 2000, Region 8, South Asia, in U.S. Geological Survey World Petroleum Assessment 2000Description and results: U.S. Geological Survey Digital Data Series DDS-60, version 1.1, 4 CD-ROMs.

Waples, D.W., and Hegarty, K, 1999, Seychelles thermal history hydrocarbon generation traced: Oil and Gas Journal, v. 97, no. 21, p. 78-82.

Warwick, P.D., Javed, S., Mashhadi, S.T.A., Shakoor. T., Khan, A.M., and Khan, A.L., 1993, Lithofacies and palynostratigraphy of some Cretaceous and Paleocene rocks, Surghar and Salt Range coal fields, northern Pakistan: U.S. Geological Survey Bulletin 2096, $35 \mathrm{p}$.

Warwick, P.D., and Shakoor. T., 1993, Lithofacies and depositional environments of the coal-bearing Paleocene Patala Formation, Salt Range coal field, northern Pakistan: Geological Survey of Pakistan, Project Report (IR)PK-109.5, 52 p.

Zaigham N.A., and Mallick, K.A., 2000, Prospect of hydrocarbon associated with fossil-rift structures of the southern Indus Basin, Pakistan: American Association of Petroleum Geologists Bulletin, v. 84, no. 11, p. 1833-1848.

\section{Figure Captions}

Figure 1. Location of the Kohat-Potwar geologic province is shown in green (8026), other assessed provinces within Region 8 are shown in yellow. Region 8 geologic provinces as defined for the U.S. Geological Survey World Energy Project are numbered, and those not assessed are shown in brown; adjacent regions are shown in gray.

Figure 2. Generalized geology of the Kohat-Potwar geologic province and surrounding area (modified from OGDC, 1997; Wandrey and Law, 1999; Wandrey and others, 2000).

Figure 3. Generalized structure of Kohat-Potwar geologic province area (modified from Kazmi and Rana 1982; Khan and others 1986; Law and others 1998).

Figure 4. Extent of total petroleum systems in the Kohat-Potwar geologic province area.

Figure 5. Generalized stratigraphy of the Kohat-Potwar area (modified from OGDC, 1996; Quadri, 1996; Kemal, 1992; Iqbal and Shah, 1980; Shah and others, 1977).

Figure 6. Paleogeographic map of the Middle Jurassic (approximately $166 \mathrm{Ma}$ ). Perspective is from lat $20^{\circ} \mathrm{S}$., long $68^{\circ} \mathrm{E}$. (modified 
from Scotese and others, 1988; Scotese, 1997).

Figure 7. Paleogeographic map of the Early Cretaceous (approximately $130 \mathrm{Ma}$ ). Perspective is from lat $20^{\circ} \mathrm{S}$. long $^{\circ} 68^{\circ} \mathrm{E}$. (modified from Scotese and others, 1988; Scotese, 1997).

Figure 8. Paleogeographic map of the Late Cretaceous (approximately $94 \mathrm{Ma}$ ). Perspective is from lat $20^{\circ} \mathrm{S} .$, long $^{\circ} 68^{\circ} \mathrm{E}$. (modified from Scotese and others, 1988; Scotese, 1997).

Figure 9. Paleogeographic map of the latest Cretaceous (approximately $69 \mathrm{Ma}$ ). Perspective is from lat $20^{\circ} \mathrm{S}$., long $68^{\circ} \mathrm{E}$. (modified from Scotese and others, 1988; Scotese, 1997).

Figure 10. Paleogeographic map of the middle Eocene (approximately $50 \mathrm{Ma}$ ). Perspective is from lat $20^{\circ} \mathrm{S}$., long $68^{\circ} \mathrm{E}$. (modified from Scotese and others, 1988; Scotese, 1997).

Figure 11. Paleogeographic map of the late Oligocene Epoch (approximately $27 \mathrm{Ma}$ ). Perspective is from lat $20^{\circ} \mathrm{S} .$, long $^{\circ} 68^{\circ} \mathrm{E}$. (modified from Scotese and others, 1988; Scotese, 1997).

Figure 12. Generalized cross section showing structure through the Potwar Plateau (modified from Malik and others, 1988). See figure 13 for location of fields used on cross section.

Figure 13. Generalized oil and (or) gas fi eld and structure map of Kohat-Potwar area (modified from Kemal, 1992; Government of Pakistan, 2001; Kazmi and Rama, 1982; Khan and others, 1986; Law and others, 1998; Petroconsultants, 1996).

Figure 14. Plot showing the cumulative number of new-field wildcat wells versus well-completion year. This plot is an indicator of exploration effort. Based on Petroconsultants well and field data (Petroconsultants, 1996).

Figure 15. Maturity of exploration indicator plots showing known and grown (expected final size when production is ended) field sizes grouped in thirds by age of discovery and ranked by size. Based on Petroconsultants field data (Petroconsultants, 1996).

Figure 16. Plots showing cumulative known and grown oil volumes versus the cumulative number of new-field wildcat wells. The trends exhibited indicate continued success in finding relatively consistent volumes of oil with a similar amount of exploration effort. Based on Petroconsultants field data (Petroconsultants, 1996).

Figure 17. Plot showing field size versus field-discovery year serves as an indicator of exploration maturity. Based on Petroconsultants filed data (Petroconsultants, 1996).

Figure 18. Plot showing reservoir depth versus oil-field-discovery year. This plot shows increasing depth of discoveries through time. Based on Petroconsultants field data (Petroconsultants, 1996).

Figure 19. Generalized cross section showing structure through the Potwar Plateau (modified from Malik and others, 1988) and generalized maturity profile (modified from OGDC, 1996).

Figure 20. Generalized burial-history plots for the ODGC Dakhni 1 well (left) and the Gulf Oil Fim Kassar well (right) (modified from Law and others, 1998).

Figure 21. Distribution of producing reservoirs by age and number of fi elds in which they occur (based on Petroconsultants reservoir and field data; Petroconsultants, 1996).

Figure 22. Distribution of producing reservoirs by age, lithology, and number of fields reporting production from that age group and lithology type. Based on Petroconsultants fi eld and reservoir data (Petroconsultants, 1996).

Figure 23. Petroleum system events chart for the Kohat-Potwar geologic province. Colored bars that fill less than the full height of the event box indicate the event only occurred in parts of the basin. 


\section{Table Captions}

Table 1. Estimates of undiscovered oil and gas for the Patal-Nammal composite total petroleum system, Kohat-Potwar geologic province (8026), Pakistan.

[MMBO, million barrels of oil. BCFG, billion cubic feet of gas. MMBNGL, million barrels of natural gas liquids. MFS, minimum field size assessed (MMBO or BCFG). Prob., probability (including both geologic and accessibility probabilities) of at least one fi eld equal to or greater than the MFS. Results shown are fully risked estimates. For gas fields, all liquids are included under the NGL (natural gas liquids) category. F95 represents a 95percent chance of at least the amount tabulated. Other fractiles are defined similarly. Fractiles are additive under the assumption of perfect positive correlation. Shading indicates not applicable]

Table 2. Expected size distribution for undiscovered oil fields in the Kohat-Potwar geologic province.

Table 3. Expected size distribution for undiscovered gas fields in the Kohat-Potwar geologic province.

Manuscript approved for publication January 9, 2004 Published in the Central Region, Denver, Colorado Editing, page layout, photocomposition, Richard W. Scott, Jr. Section 508 compliance, David G. Walters Webmaster. Tracy A. Pinto Graphics by the authors 